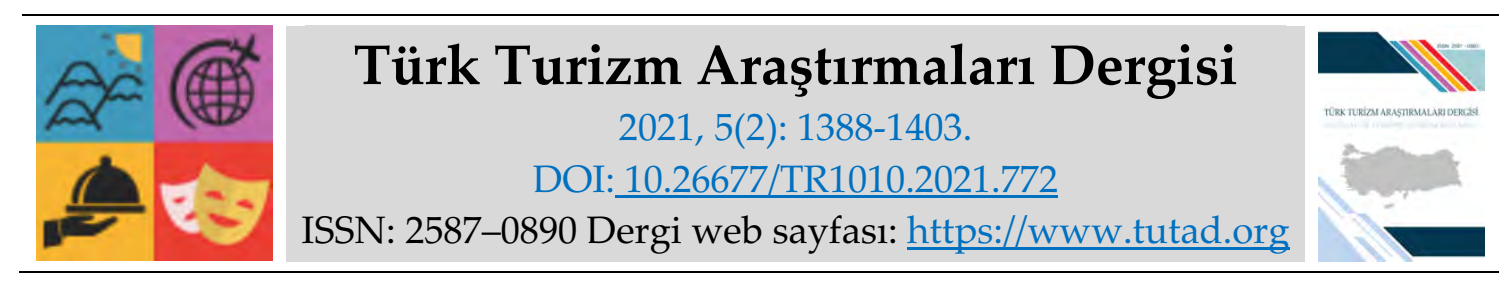

ARASTTIRMA MAKALESI

\title{
Bisiklet Turizmi Bağlamında Bisiklet Dostu Şehir Uygulamalarına Yönelik Bir Araştırma: Twitter Örneği
}

Dr. Öğr. Üyesi F. Kübra AYLAN, Selçuk Üniversitesi, Turizm Fakültesi, Konya, e-posta: kubraceliloglu@gmail.com

ORCID: https://orcid.org/0000-0002-6703-2934

Öz

Bisiklet turizmi, bir dizi ekonomik, sosyal ve çevresel fayda sağlama potansiyeline sahip, büyüyen bir niş turizm pazarıdır. Çalışmanın amacı bisiklet turizmi açısından bisiklet dostu şehir uygulamalarının tespit edilmesidir. Bu amaç doğrultusunda sosyal medya uygulaması olan Twitter'da 2013 Haziran- 2021 Ocak tarihleri arasında "bisiklet dostu şehirler", "bisiklet dostu kentler", "bisiklet şehri" başlıkları ile yapılan 123 paylaşım (tweet) araştırma verisini oluşturmaktadır. Elde edilen veriler Maxqda nitel analiz programı aracılığıyla içerik analizine tabi tutulmuştur. Sonuç olarak bu konuda en fazla paylaşım 2020 yılında yapılmış olup, paylaşımların içeriğinde, bisiklet dostu şehirler, şehirlerin bisiklet dostu uygulamaları, rekreatif faaliyet açısından bisikletin değerlendirilmesi ve bisiklet kullanımı ile ilgili ifadeler bulunmaktadır. Bisiklet dostu şehir olarak, ABD, Almanya, Avusturya, Belçika, Danimarka, Finlandiya, Fransa, Hollanda, İspanya, Kolombiya, Macaristan, Norveç ve Türkiye'den kentlerin gösterildiği tespit edilmiştir.

Anahtar Kelimeler: Bisiklet Turizmi, Bisiklet Dostu Şehirler, Twitter, Maxqda.

Makale Gönderme Tarihi: 14.02 .2021

Makale Kabul Tarihi: 01.06.2021

\section{Önerilen Atıf:}

Aylan, F. K. (2021). Bisiklet Turizmi Bağlamında Bisiklet Dostu Şehir Uygulamalarına Yönelik Bir Araştırma: Twitter Örneği, Türk Turizm Araştırmaları Dergisi, 5(2): 1388-1403.

(C) 2021 Türk Turizm Araştırmaları Dergisi. 


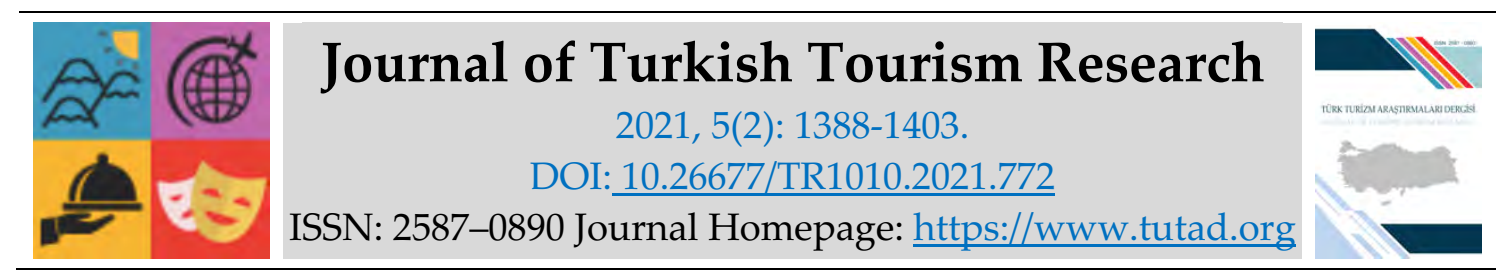

\title{
$\underline{\text { RESEARCH PAPER }}$
}

\section{A Research on Bicycle Friendly City Practices in The Context of Bicycle Tourism: Case of Twitter}

Assistant Prof. Dr. F. Kübra AYLAN, Selçuk University, Faculty of Tourism, Konya, e-mail: kubraceliloglu@gmail.com ORCID: https://orcid.org/0000-0002-6703-2934

\begin{abstract}
Bicycle tourism is a growing niche tourism market with the potential to deliver a range of economic, social and environmental benefits. The aim of the study is to determine bicycle-friendly city applications in terms of bicycle tourism. For this purpose, 123 posts (tweets) made on Twitter, a social media application, between June 2013 and January 2021 with the titles "bicycle friendly cities", "bicycle friendly towns", "bicycle city" constitute the research data. The data obtained were subjected to content analysis through the Maxqda qualitative analysis program. As a result, the most sharing on this issue was made in 2020, and the posts included expressions about bicyclefriendly cities, the practices of cities, the evaluation of recreational activities and the use of bicycles. It has been determined that cities in the US, Germany, Austria, Belgium, Denmark, Finland, France, Netherlands, Spain, Colombia, Hungary, Norway and Turkey have been displayed as Bicycle-friendly cities.
\end{abstract}

Keywords: Bicycle Tourism, Bicycle Friendly Cities, Twitter, Maxqda.

Received: 14.02 .2021

Accepted: 01.06.2021

\section{Suggested Citation:}

Aylan, F. K. (2021). A Research on Bicycle Friendly City Practices in The Context of Bicycle Tourism: Case of Twitter, Journal of Turkish Tourism Research, 5(2): 1388-1403.

(C) 2021 Türk Turizm Araştırmaları Dergisi. 


\section{Gíriş}

Evrensel olarak neredeyse motorlu taşıtlar etrafında tasarlanan kentsel alanlar, hava kirliliğii, trafik sıkışıklığı, fiziksel ve zihinsel sağlığın bozulması ve iklim değişikliği gibi önemli zorluklarla karşı karşıyadır (ARUP, 2019). Meydana gelen bu çevre kirliliği, artan yakıt tüketimi, sürekli trafik sıkışıklığı ve sağlığın bozulması şehirlerde insan hayatını tehdit eden ana sorunlardan bazılarıdır. Genel olarak motorlu taşıtların yerine bisikletin tercih edilmesi sonucunda kentsel hareketlilik, çevresel ve sosyal fayda açıdan iyileşmeler meydana gelmektedir. Sağlı̆̆g geliştiren, çevreye zarar vermeyen ve mali açıdan yararlı seyahat biçimleri olarak yürüme ve bisiklet sürmenin bireylere ve topluma sağladığı faydalar artık bilimsel çalışmalar ile desteklenmiş ve giderek daha fazla kabul görmüştür (Handy, 2020:169). Şehirlerin bisiklet kullanımına daha uygun ve bisiklete binmeyi daha çok teşvik edecek şekilde geliştirilmesi, sadece akademik araştırma düzeyinde değil, aynı zamanda mesleki uygulamada da en önemli kentsel trendlerden biri olarak kabul edilmektedir. Bisiklet dostu şehir (Bicycle Friendly City-BFC) kavramı, özellikle Avrupa ülkelerinde, 21. yüzyılda kentsel gelişim planlarının ana hedeflerinden biri olarak uluslararası alanda ortaya çıkmıştır (Zayed, 2016:211). Kentsel tasarımında bisiklet dostu uygulamaların hayata geçirilmesi sayesinde bisiklet kullanım oranının yükseldiği varsayılmaktadır (Titze, Krenn ve Oja, 2012:29). Handy (2020) çalışmasında, yaya ve bisiklet dostu şehirleri, insan dostu şehirler olarak da nitelendirmektedir. Şehirlerin bisiklet dostu uygulamaları hem kalkınma aracı olarak hem de alternatif bir turizm türü olan bisiklet turizminden daha fazla pay almaları açısından önem arz etmektedir.

Bisiklet turizmi; macera turizmi (Lamont, 2009), eko-turizm (Sağlik vd., 2014), sürdürülebilir turizm (Soyalp, 2018) ve sorumlu turizm (Neves ve Esperança, 2011) ile ilişkilendirilmekle birlikte turizm sektöründe önemli bir niş pazar oluşturmaktadır. Literatür taraması sonucunda bisiklet turizmi ile yapılan akademik çalışmalar incelendiğinde; bisiklet turizmi ve ekonomik kalkınma (Pratte, 2006; Beierle, 2011; Lee, 2015), bisiklet turizmi (Simonsen, 1998; Lamont, 2009; Chang ve Chang, 2013), bisiklet turizmi ve motivasyon (Faulks vd., 2008), bisiklet dostu şehirlerin yollarının güvenliği (Wesley, 2011), bisiklet kullanımı ve bisiklet turizmi (Neves ve Esperança, 2011), tatil bisikleti için bisiklet paylaşımı (Kaplan, 2014), bisiklet dostu olmaya yönelik kentsel hazırlık durumu (Zayed, 2016), bisiklet turizminde destinasyon ve etkinlik yönetimi (Buning ve Gibson, 2016), bisiklet turizmi katılımcılarının tatil deneyimi (Soyalp, 2017), sürdürülebilirlik ve bisiklet turizmi (Gazzola, 2018), alternatif turizm türü (Duran, Sevinç ve Harman, 2018), kentsel bisikletlenebilirlik endeksi (Titze, 2012; Arellanaa vd., 2020; Chevalier ve Xu, 2020; Kamel vd., 2020), bisiklet paylaşımı (Lyua, 2020) ve bisiklet turistleri için önemli olan altyapı faaliyetleri (Griswold vd., 2011; Strauss ve Miranda-Moreno, 2013) konularının çalışıldığı ortaya çıkmıştır. Bisiklet dostu şehir uygulamalarının bisiklet turizmi bağlamında inceleyen bir çalışmaya rastlanılmamıştır. Bu doğrultuda araştırmada sosyal medya platformu olan Twitter'dan, bisiklet dostu şehirlere yönelik yapılan paylaşım verilerinin içerik analizi sonucunda şehirlerde bisiklet dostu uygulamaların tespit edilmesi amaçlanmıştır. Çalışma bisiklet dostu şehir uygulamalarının bisiklet turizmi kapsamında turistik bir çekicilik unsuru ve destinasyon tanıtım aracı olarak değerlendirilmesi açısından önem arz etmektedir.

\section{LITERATÜR}

\section{BISIIKLET TURİMI}

Bisiklet, modern yaşamda kısa mesafe ulaşım aracı olarak kabul edilmektedir (Cengiz ve Kahvecioğlu, 2016:56). Bisikletin, kadın-erkek ve çocuklar-yetişkinler gibi kullanıcı özelliklerine ve aktivitelere göre çeşitli türleri bulunmaktadır. İki kişilik (tandem, çocuk alıştırma bisikleti), üç 
tekerlekli (pedi-cab), kargo bisikleti ve polis bisikleti, dünya çapında iyi bilinen bisiklet türlerindendir. Bisiklet, çocukların ve gençlerin vücutlarının sağlıklı büyümesine, yetişkinlerin kalp ve damarlarını etkileyen birçok hastalığı önlemesine katkı sağlamaktadır (Bauman ve Rissel, 2009). Kadınlar bisikletli bir topluluğun "gösterge türü" olarak görülmektedir. Çünkü kadınlar tarafından yapılan bisiklet gezilerinin oranı, bisiklet koşullarının ne kadar güvenli olarak algılandığını ölçmek için önemli bir göstergedir. Vancouver, British Columbia ve Portland gibi şehirlerde kadınlar için kapsamlı bisiklet programları bulunmaktadır (Barney, 2018:3). Amerikan Bisikletliler Ligi 2012'de "Kadın Bisikleti" kampanyasını daha fazla kadının bisiklete binmesini sağlamak amacıyla başlatmıştır (Handy, 2020:178). Bisiklet aynı zamanda önemli bir turistik ürün haline gelmiştir.

19. yüzyılın sonlarında başlayan bisiklet turizmi (Lamont, 2009) günümüzde, hızlı bir ivme kazanmıştır (Weston vd., 2012). Ritchie (1998:569) bisiklet turizmini, 24 saatten daha uzun süre rekreatif amaçlı yapılan tatillerde bisikletli tüm faaliyetler olarak tanımlamaktadır. Sustrans (1999) bisiklet turizmini, ziyaretin temel ve önemli bir parçası olan bisiklet ile evden uzakta yapılan günlük ziyaretler olarak tanımlamıştır. Faulks, Ritchie ve Dodd (2008:3) bisiklet turizmini, bir bisiklet etkinliğini izlemeyi, bağımsız veya organize bisiklet turlarına katılmayı içeren bir turizm türü olarak ifade etmektedir. Lamont (2009), bireylerin bisiklet kullanıcısı olduğu tatilleri aktif bisiklet turizmi ve bisiklet etkinliklerini izlemek amacıyla yapılan pasif bisiklet turizmi olarak iki sınıflandırmaya tabi tutmaktadır. Bu tanımların ortak noktası, gezinin ana amacı olmayan tesadüfi bisiklet, bisiklet turizmi olarak değerlendirilmemesidir (Faulks vd., 2008:3). Neves ve Esperança (2011:193) bisiklet turizmini, çevre dostu, fiziksel ve psikolojik refahı artıran, olağanüstü deneyimler sunan, kişisel gelişime katkı sağlayan sorumlu turizm gelişiminin bir parçası olan yeni bir turizm biçimi şeklinde tanımlamaktadır. Sağlık vd. (2014:84), bisiklet turizminin gelişmesinde bu sporu yapanların doğrudan katkıları olduğunu belirtmiştir. Dünyada bisiklet turizmi kapsamında İtalya, İspanya, Macaristan, Polonya (Weston vd., 2012), Avustralya (Faulks vd., 2007), Güney Afrika (Streicher ve Saayman, 2010), Finlandiya (Soyalp, 2018), Himalayalar ve Kenya'da çeşitli aktiviteler düzenlenmektedir (Sağllk vd., 2014:84). Türkiye' den bu aktivitelere örnek olarak, Muğla (Aşan ve Akoğlan Kozak, 2015), İzmir (İçöz vd., 2018), Konya (Ünüvar vd., 2017), Çanakkale (Duran vd., 2018) ve Burhaniye (Uğuz ve Özbek, 2018) illerinde gerçekleştirilen etkinlikler gösterilebilir.

Bisiklet turizmi kapsamında düzenlenen etkinlikler yerel ekonomiyi canlandırarak gelir elde edilmesine katkı sağlamaktadır (Uğuz ve Özbek, 2018:86). Bisiklet organizasyonlarının yanı sıra organizasyon katılımcıları ve izleyiciler tarafından da dışarıdan parasal girdi akışı mevcuttur (Arup, 2005). Ayrıca bisiklet turizminin sosyal ve çevresel açıdan da bir takım faydaları bulunmaktadır. Sosyal açıdan, benzer ilgi alanlarına sahip insanlar arasındaki etkileşimin yanı sıra, aerobik kapasitenin iyileştirilmesi ve obezite ile mücadele gibi genel olarak sağlıkla ilişkili faydaları içermektedir (Gibling, 2006). Bisiklet turizminin çevresel açıdan faydası esas olarak kirletici olmayan ve sürdürülebilir alternatif bir ulaşım şekli olarak kullanılmasıyla ilgilidir (Goeft ve Alder, 2001).

Bisiklet ile çeşitli aktiviteler yapan turistler, genellikle doğaya zarar vermeyen eko turizm faaliyetlerini daha çok tercih etmektedirler (Sağlık vd., 2014:84). Bisiklet turistlerinin yeni insanlarla tanışma, bağımsızlık, başarı, gerginlikten uzaklaşma, kendi kendini anlayabilme yeteneği, benzer değerleri paylaşma, doğadan zevk alma, öğrenme, fiziksel zindelik, aileyle birlikte olma, nostalji gibi birçok deneyim yaşadığı belirtilmektedir (Aşan ve Akoğlan Kozak, 2015). Bisiklet turistlerinin ziyaret noktalarında altyapı faaliyetleri yetersizliği onlar için risk oluşturmaktadır. Örneğin, Çek Cumhuriyeti'nde ölümle sonuçlanan bisiklet kazalarının en önemli nedeni hızlı hareket eden motorlu taşıtlardır, bu nedenle altyapı, bisiklet turizmi için çok önemli bir unsurdur (Soyalp, 2018). Önemli olan diğer unsurlar ise, yiyecek ve içecek tesisleri, 
hava durumu, normal yollar ve konaklama tesislerinin olduğu belirtilmektedir (Lee, Chen ve Huang, 2014). Bisikletinde fazla yiyecek ve içecek taşıyamadığından ihtiyaçlarının dış kaynak kullanımı ile alınması bisiklet turisti için önemlidir (Lamont, 2009).

\section{BISSIKLLET DOSTU ŞEHIRLER}

Uzun yıllardır motorlu ulaşım araçlarına aşıı bağımlılıktan sonra bu araçların olumsuz çevresel etkileri kabul edilmiş ve dünyanın çoğu şehri yaşam kalitelerini artırmak için motorsuz ulaşım araçlarının kullanılmasını önemsemeye başlamıştır. Bisiklet, motorlu taşıtlara karşı etkili bir alternatif olarak kabul edilmektedir. Ayrıca günümüzün geleneksel şehirlerini bisiklet dostu şehirlere dönüştürmek, kalkınma planlarının temel hedeflerinden biri olarak görülmektedir (Zayed, 2016:210). Yerel yönetimlerin, şehri araba dostu olmaktan çok insan dostu ve çevre dostu yapmaya odaklandığı belirtilmektedir (Kristinsdottir, 2012). Bu tür bir şehir, bisiklet sürmek için daha uygun alanlar yaratmaya çalışmaktadır. Bisiklet temelli kentsel gelişim, ek arazi geliştirme ihtiyacını azaltarak ve kentleşme oranlarını düşürerek, biyolojik çeşitliliği ve habitatları koruyarak olumlu ekolojik etkilere sahiptir. Sürdürülebilir bir ulaşım şekli olarak bisiklete binmenin öneminin anlaşılmasıyla, "bisiklet dostu şehir" terimi tüm dünyada kullanılmaya başlanmıştır (Zayed, 2016:212-13).

Kuzey Amerika'da kullanılan bisiklet dostu şehir terimi, bisiklet sürmeyi ana ulaşım şekli yapmak için gerekli altyapıya, ulaşım politikalarına ve toplumsal mutabakata sahip bir şehri ifade etmektedir (Kristinsdottir, 2012). Bisiklet dostu şehirlerin bölgesel özellikleri (ör. yapılı çevre, ağ yapılandırması, sosyo-demografi ve arazi kullanımı), bisiklet sürmenin çekiciliğini ve güvenliğini etkilemektedir (Kamel, Sayed ve Bigazzi, 2020). Araştırmalar, bisiklet gezilerinin bisiklet altyapısı, trafik güvenliği, konfor ve çekicilik, istihdam yoğunluğu ve arazi kullanımı gibi çevre özellikleriyle olumlu bir şekilde ilişkili olduğunu göstermektedir (Griswold vd., 2011; Strauss ve Miranda-Moreno, 2013). Ayrica bisiklet kullanma potansiyelinin, hava durumu ve kültür gibi faktörlerden etkilendiği belirtilmektedir (Handy, 2020:171). Bu nedenle, bisiklet kullanımına uygun kentsel alanların tasarımı, çok boyutlu anlamda sürdürülebilir olan şehirlerin gelişmesi için gereklidir. Şehirlerde genel olarak, iki tür bisiklet paylaşım planı vardır. İlki, yerleştirilmiş bisiklet paylaşım planı olarak bilinir; bu, bisikletlerin bir yerleştirme istasyonundan ödünç alınabileceği, kullanılabileceği ve daha sonra başka bir yerleştirme istasyonuna iade edilebileceği anlamına gelir. Washington, D.C., Montreal, Berlin ve Paris gibi bazı batı şehirleri, yerleşik bisiklet paylaşım planları uygulamaktadır. İkinci tür, sabit istasyonları olmayan bisiklet paylaşım şemasıdır. Kullanıcılar, bir akıllı telefon uygulamasını kullanarak bisikletleri herhangi bir yerden kolayca bulabilir ve kilidini açabilir. Bunlar, Şangay, Pekin ve Guangzhou gibi bazı Çin mega şehirlerinde yaygındır (Lyua vd., 2020).

Bisiklet, ulaşımla ilişkili çevresel etkileri azaltmanın yanı sıra, uygun fiyatlı bir ulaşım yöntemi ve sağlığı iyileştirmenin bir yolu olarak yeniden ilgi görmektedir (Barney, 2018:1). Bu nedenle destinasyon yönetim örgütleri, halk sağlı̆̆ını korumak ve şehrin yaşam ortamının iyileştirilmesine katkı sağlamak amacıyla aktif ulaşım şekillerinden yürüme ve bisiklet kullanımını teşvik etmeye başlamıştır (Kamel, Sayed ve Bigazzi, 2020). Bisiklet hem yetişkinler hem de çocuklar için, fiziksel aktivite, hareketlilik fırsatı, sağlıklı bir yaşam ve ekonomik tasarruf sağlaması açısından oldukça faydalıdır (Oja vd., 2011). Ayrıca kilo kontrolü ve obezitenin en aza indirilmesi bisiklete binme ile pozitif yönde ilişkilidir (Bassett vd., 2008). Özetle bisiklet, yolcuların fiziksel ve zihinsel sağlığını iyileştirir, araç emisyonlarını ve seyahat sürelerini azaltır ve maliyet tasarrufu sağlar. Bireylere ve topluma sunduğu çok çeşitli faydalar nedeniyle, dünyadaki birçok hükümet bisiklet sürmeyi teşvik etmek için girişimleri ve politikaları teşvik etmektedir (Arellanaa vd., 2020:310). Bu doğrultuda bisiklet dostu şehirlerin tespit edilmesinde 
Copenhagenize Index'i önemli bir yere sahiptir. Kentsel tasarım danışmanlığı yapan Copenhagenize Index'i, 2011'den bu yana her iki yılda bir bisiklet dostu şehirleri seçmektedir. Bisiklet dostu şehirlerin seçiminde yapılan puanlamada, bisiklet altyapısı, bisiklet olanakları, trafik koşulları, güvenlik göstergeleri, kadın-erkek dengesi, bisiklet imajı, kargo bisikletler, ortak bisiklet programı, siyasilerin ve sivil toplum örgütlerinin politikaları, şehir planlaması gibi kriterler göz önüne alınmaktadır (www.copenhagenizeindex.eu) Copenhagenize Index'inin 2019 raporuna göre bisiklet dostu şehirlerin sıralaması aşağıda Tablo 1'de gösterilmektedir.

Tablo 1. Bisiklet Dostu Şehirlerin Sıralaması

\begin{tabular}{|c|c|c|c|c|c|}
\hline Siralama & 2011 & 2013 & 2015 & 2017 & 2019 \\
\hline 1. & Amsterdam & Amsterdam & Kopenhag & Kopenhag & Kopenhag \\
\hline 2. & Kopenhag & Kopenhag & Amsterdam & Utrecht & Amsterdam \\
\hline 3. & Barselona & Utrecht & Utrecht & Amsterdam & Utrecht \\
\hline 4. & Berlin & Seville & Eindhoven & Strasbourg & Anvers \\
\hline 5. & Tokyo & Bordeaux & Malmö & Malmö & Strasbourg \\
\hline 6. & Münih & Nantes & Nantes & Bordeaux & Bordeaux \\
\hline 7. & Paris & Antwerp & Bordeaux & Antwerp & Oslo \\
\hline 8. & Montreal & Eindhoven & Strasbourg & Lübliyana & Paris \\
\hline 9. & Dublin & Malmö & Antwerp & Tokyo & Viyana \\
\hline 10. & Budapeşte & Berlin & Seville & Berlin & Helsinki \\
\hline 11. & Hamburg & Dublin & Barselona & Barselona & Bremen \\
\hline 12. & Guadalajara & Tokyo & Lübliyana & Viyana & Bogota \\
\hline 13. & Portland & Münih & Dublin & Paris & Barcelona \\
\hline 14. & Stockholm & Montreal & Benos Aires & Seville & Lübliyana \\
\hline 15. & Helsinki & Nagoya & Berlin & Münih & Berlin \\
\hline 16. & Londra & Rio de Janeiro & Minneapolis & Nantes & Tokyo \\
\hline 17. & San Francisco & Barselona & Paris & Hamburg & Taipei \\
\hline 18. & Rio de Janeiro & Budapeşte & Hamburg & Helsinki & Montreal \\
\hline 19. & Viyana & Paris & Münih & Oslo & Vancouver \\
\hline 20. & New York & Hamburg & Montreal & Montreal & Hamburg \\
\hline
\end{tabular}

Günümüzde Avrupa, Amerika ve Avustralya'daki birçok şehir, bisikleti birincil ulaşım aracı olarak yeniden canlandırmak için girişimde bulunmaktadır (Buehler ve Pucher, 2012). Hollanda bu konudaki yoğun çalışması ile 1970'lerde azalan uygulamaları yeniden keşfetmiş ve kısa süre sonra "bisiklet sürme ülkesi" imajını geliştirmiş (Chevalier ve Xu, 2020:67) olup, Copenhagenize Index'inde 2011 ve 2013 yıllarında Amsterdam şehri ile ilk sırada yer almıştır. 2015, 2017 ve 2019 yıllarında bisiklet dostu şehirler sıralamasında ilk sırada yer alan Kopenhag'ın bisiklet dostu uygulamalarına en iyi örnek "Döngü Yılanı Köprüsü" (Danca Cykelslangen) olarak bilinen Kopenhapen'deki en ikonik bisiklet yolu gösterilebilir. Bu üst geçit, 2014 yılında açılan ve günde 20.000 'den fazla bisikletçiye ev sahipliği yapan 230 metre uzunluğunda bir gökyüzü köprüsüdür. Parlak turuncu rengi ve bütün gece yanık olan LED ışıkları ile tanınmaktadır (kp15.kk.dk).

Özetle bisiklet kullanımı, insanların zihinsel ve fiziksel gelişimine, şehirlerin çevresel, sosyal, ekonomik kalkınmasına ve yaşanabilirliğine katkı sağmaktadır. Turizm sektörü açısından ise, bisiklet kullanımı önemli bir turistik ürünü oluşturmaktadır. Bu doğrultuda çalışmada, bisiklet turizmi kapsamında bisiklet dostu şehir uygulamaları incelenmiştir.

\section{ARAŞTIRMA YÖNTEMI}

Araştırmanın amacı bisiklet turizmi kapsamında bisiklet dostu şehir uygulamalarına yönelik sosyal medyada yapılan paylaşımların incelenmesi ve bu uygulamaların tespit edilmesidir. Bu 
amaç doğrultusunda araştırma metodu olarak, nitel araştırma yöntemi kullanılmıştır. Nitel araştırma yöntemi sosyal bilimler alanında son yıllarda sıklıkla kullanılmaktadır (Çelik vd., 2020:380). Nitel araştırma, incelediği probleme ilişkin sorgulayıcı, yorumlayıcı ve problemin doğal ortamındaki biçimini anlama uğraşı içinde olan bir yöntemdir (Baltac1, 2019:369). Nitel çalışmalarda, analiz süreci esas olarak ham verilerin hacmini azaltarak büyük miktardaki verilerin özü anlaşılmaya çalışılır (Patton, 2014). Özü çıkarılan küçük parçalar genel söylemi oluşturmada önemli rol oynar. Nitel araştırmalar incelikli ayrıntıları ve nitelikleri temel alarak, olanı anlamak yerine onu göstermeye ve bir anlamda duyguyu iletmeye odaklanmaktadır. Bu şekilde araştırmada veriler derinlemesine betimlenmekte, yorumlanmakta ve çalışmada kişilerin bakış açılarının anlaşılması amaçlanmaktadır (Mamur, 2012:4-5).

Araştırmada yazılı belgelerin ayrıntılı olarak taranması yoluyla doküman/metin incelemesi yöntemi kullanılmıştır (Creswell, 2002). Sosyal medya uygulaması olan Twitter'da 2013 Haziran2021 Ocak tarihleri arasında "bisiklet dostu şehirler", "bisiklet dostu kentler", "bisiklet şehriler" başlıkları ile yapılan 123 paylaşım (tweet) araştırma verisini oluşturmaktadır. Elde edilen veriler içerik analizine tabi tutulmuştur. İçerik analizi genellikle çok sayıdaki metin içeriklerinin ortak yönlerini ortaya çıkarmak amacıyla, önemli olan anlamların yapılandırılmasına ve sınıflandırılmasına yönelik, nitelden nicele doğru genelleştirmeyi sağlayan bir yorum biçimidir (Gökçe, 2006:17-18; Karadă̆, 2015:5). Çalışmada verilerin teker teker okunması yoluyla kod ve kategorilere dayalı olarak araştırma bulguları oluşturulmuştur (Merriam, 1998:58). Bu araştırmada kodlamalar, verilerden çıkarılan kavramlara göre yapılmıştır (Strauss ve Corbin, 1990). Araştırmada nitel veri analizi için MAXQDA 2018 programı kullanılmıştır. MAXQDA vaka temelli nitel veri analiz sürecinde araştırmacıları desteklemektedir (Kuckartz ve Kuckartz, 2002). Araştırma soruları şu şekilde oluşturulmuştur:

* Twitter'da bisiklet dostu şehirlere yönelik yapılan paylaşımların içeriklerine göre kategorik dağılımı nasıldır?

* Twitter'da bisiklet dostu şehirlere yönelik yapılan paylaşımların yıllara göre dağılımı nasıldır?

* Twitter'da bisiklet dostu şehirlere yönelik yapılan paylaşımlarda şehirlerin dağılımı nasıldır?

* Twitter'da bisiklet dostu şehirlere yönelik yapılan paylaşımlarda hangi görseller kullanılmaktadır?

Araştırmanın güvenirliliği için Roberts ve Priest (2006), verilerin bağımsız bir araştırmacıya gönderilerek yapılan analizler ve elde edilen bulgular hakkında geri bildirim alınabileceğini belirtmiştir. Bu doğrultuda araştırmanın güvenirliğini sağlamak için elde edilen bulgular alanında uzman bir araştırmacıya gönderilmiş ve geri bildirim alınmıştır (Yıldız, 2016).

\section{BULGULAR}

Tablo 2'de sosyal medya platformu olan Twitter'dan "Bisiklet Şehri", "Bisiklet Dostu Şehirler" ve "Bisiklet Dostu Kentlere" yönelik yapılan paylaşımların içerik analizi sonucunda elde edilen kategori-temaların dağılımı ve kodlama sayıları verilmektedir. Elde edilen verilerin "Paylaşımların İçerik Dağılımları", "Bisiklet Dostu Şehirler", "Paylaşım Yılı" ve "Fotoğraflar" olmak üzere 4 kategoriye ayrıldığı tespit edilmiştir. Bu 4 kategori altında temalar oluşturulmuştur. "Paylaşımların İçerik Dağılımları" kategorisi altında 6 tema bulunmaktadır. Bunlar; bisiklet dostu şehirler $(n=30)$, şehirlerin bisiklet dostu uygulamaları $(n=59)$, rekreatif faaliyet $(n=33)$, bisiklet kullanımı $(\mathrm{n}=2)$, ulaşım ile ilgili $(\mathrm{n}=4)$ ve olumsuz $(\mathrm{n}=2)$ adlı temalardır. "Bisiklet Dostu Şehirler" kategorisi, $\operatorname{ABD}(n=1)$, Almanya $(n=3)$, Avusturya $(n=3)$, Belçika $(n=1)$, Danimarka $(n=6)$, Finlandiya $(n=1)$, Fransa $(n=4)$, Hollanda $(n=6)$, İspanya $(n=1)$, Kolombiya $(n=1)$, Macaristan $(n=1)$, 
Norveç $(\mathrm{n}=1)$ ve Türkiye $(\mathrm{n}=80)^{\prime}$ den kentlerin oluşturduğu 13 temadan oluşmaktadır. "Paylaşım $Y \imath l l^{\prime \prime}$ kategorisi, 10 temadan oluşmaktadır. Fotoğraf kategorisinin ise, altında bir tema bulunmamaktadır. Bu kategoride bisiklet dostu uygulamaların çeşitliliğini göstermek amacıyla 36 kodlama yapılmışır. Bu konuda en fazla paylaşımın 2020 yılında $(n=48)$ ve 2019 yılında $(n=22)$ yılında yapıldığg görülmektedir.

Tablo 2. Twitter'da Bisiklet Dostu Şehirlere Yönelik Yapılan Paylaşımların Kategori-Kod Sayılarının Dağılımları

\begin{tabular}{|c|c|c|c|}
\hline Kod Rengi & Kategori & Tema & Kodlama Sayısı \\
\hline - & \multirow{6}{*}{ 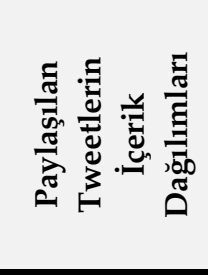 } & Bisiklet Dostu Şehirler & 30 \\
\hline$\bullet$ & & Şehirlerin Bisiklet Dostu Uygulamaları & 59 \\
\hline$\bullet$ & & Rekreatif Faaliyet & 33 \\
\hline - & & Bisiklet Kullanımı & 2 \\
\hline - & & Ulaşım ile İlgili & 4 \\
\hline 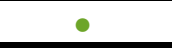 & & Olumsuz & 2 \\
\hline$\bullet$ & \multirow{9}{*}{ 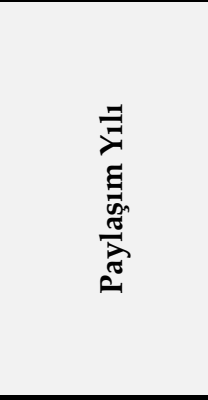 } & 2021 & 11 \\
\hline$\bullet$ & & 2020 & 48 \\
\hline - & & 2019 & 22 \\
\hline$\bullet$ & & 2018 & 11 \\
\hline - & & 2017 & 8 \\
\hline - & & 2016 & 11 \\
\hline - & & 2015 & 3 \\
\hline - & & 2014 & 1 \\
\hline - & & 2013 & 4 \\
\hline - & \multirow{13}{*}{ 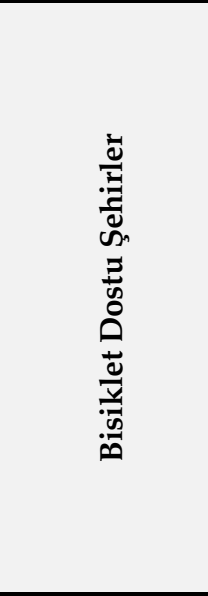 } & $\mathrm{ABD}$ & 1 \\
\hline - & & Almanya & 3 \\
\hline - & & Avusturya & 3 \\
\hline$\bullet$ & & Belçika & 1 \\
\hline$\bullet$ & & Danimarka & 6 \\
\hline - & & Finlandiya & 1 \\
\hline - & & Fransa & 4 \\
\hline$\bullet$ & & Hollanda & 6 \\
\hline - & & İspanya & 1 \\
\hline - & & Kolombiya & 1 \\
\hline - & & Macaristan & 1 \\
\hline - & & Norveç & 1 \\
\hline - & & Türkiye & 80 \\
\hline$\bullet$ & Fotoğraflar & - & 36 \\
\hline$\bullet \bullet \bullet \bullet$ & Toplam & - & 405 \\
\hline
\end{tabular}




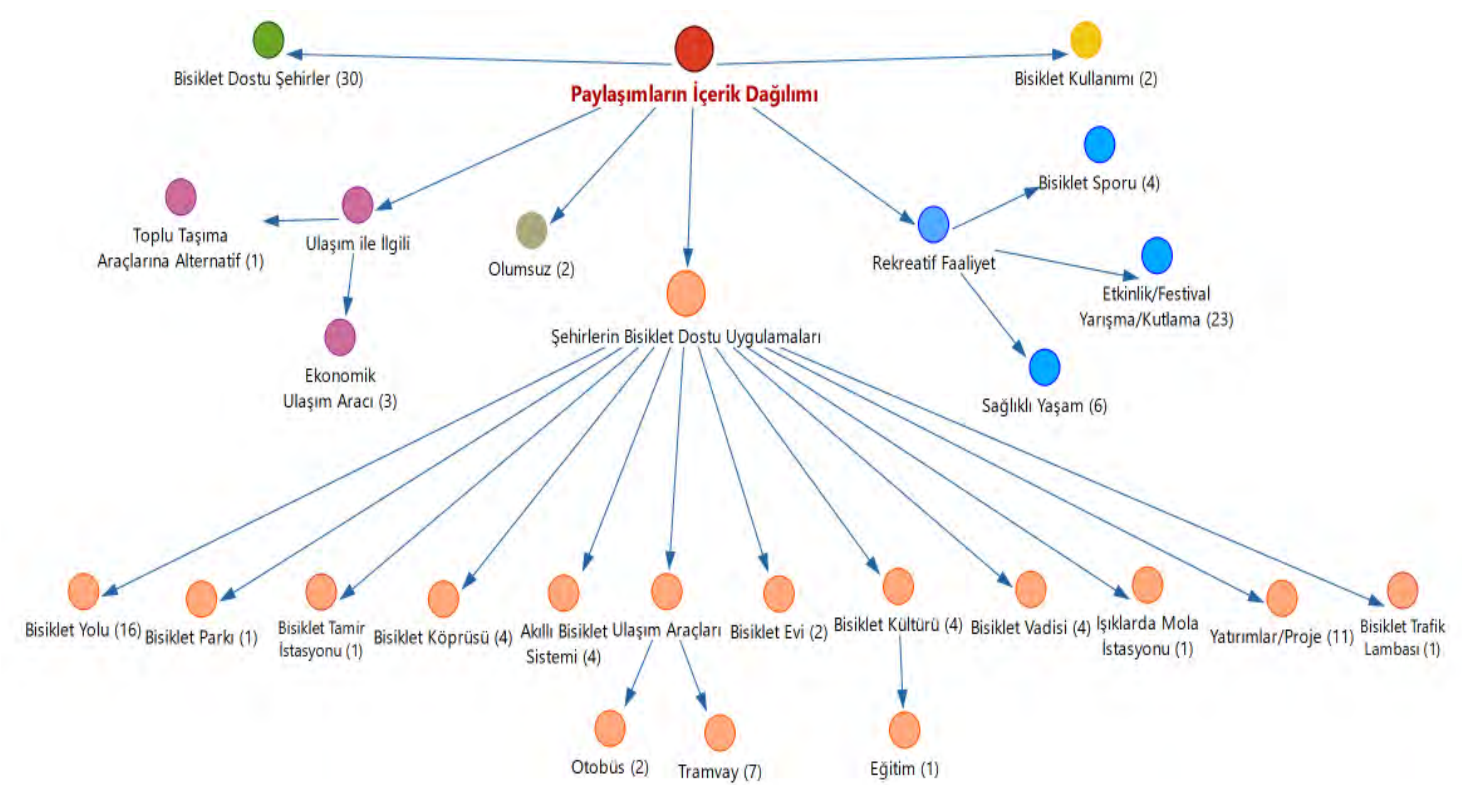

Şekil 1. Paylaşımların İçeriklerinin Hiyerarşik Kod Modeli

Bisiklet dostu şehirlere yönelik yapılan paylaşımların içeriği incelendiğinde 6 farklı konudan bahsedildiği tespit edilmiştir (Şekil 1). Paylaşımlarda bisiklet dostu şehirlere $(\mathrm{n}=30)$ yönelik genel ifadeler ile birlikte bisiklet kullanımından $(n=2)$ bahsedilmektedir. Bisiklet kullanımının toplu taşıma araçlarına alternatif $(n=1)$ ve ekonomik bir ulaşım aracı $(n=3)$ olduğu belirtilmiştir. Rekreatif bir faaliyet olarak, etkinliklerde $(n=23)$, sağliklı yaşam $(n=6)$, ve spor amaçlı $(n=4)$ bisiklet sürüldüğü belirtilmektedir. Şehirlerin bisiklet dostu uygulamalarına yönelik, bisiklet yollarından $(\mathrm{n}=16)$, bisiklet parkından $(\mathrm{n}=1)$, bisiklet köprülerinden $(\mathrm{n}=4)$, akıllı bisiklet sisteminden $(n=4)$, otobüs ve tramvayda bisiklet taşıma imkânlarından $(n=9)$, bisiklet evinden $(n=2)$, bisiklet kültürünü oluşturmaya yönelik girişimlerden $(n=5)$, bisiklet vadisi $(n=4)$, mola istasyonlarından $(n=1)$ ve bisiklet dostu şehir olma yolunda yapılan yatırım ve projelerden( $n=11)$ bahsedilmiştir. Paylaşımlara örnek olarak; "Bisiklet hayattır. Sakarya ise bisiklet sporunun başkentidir" (Bisiklet Sporu). "Dünyanın en büyük ve en modern bisiklet vadisiyle ülkemizde" (Bisiklet Vadisi). "Bisiklet, sağlıklı ve en ekonomik ulaşım aracıdır" (Sağlıklı, Ekonomik Ulaşım Aracı). "Hollanda Utrecht'da, ulaşımın \% 60'ı bisikletle sağlanıyor. Ana tren istasyonunda 12.000 bisiklet kapasiteli bisiklet park yeri var, 2020 de 33.000 kapasiteye ulaşacak. Günlük 24.000 bisikletli bisiklet yollarım kullanıyor. Bisiklet dostu bir şehir"(Bisiklet Kullanımı, Bisiklet Park Yeri, Bisiklet Yolları). "550 km ile Türkiye'nin en uzun bisiklet yolunun bulunduğu Konya'da bisiklet kültürünü ve farkındalı̆ğ artırmaya yönelik çalışmaları artırmak için çalışmalar devam ediyor" (Bisiklet Yolu, Bisiklet Kullanım Kültürü Oluşturma). Spor alanları, bisiklet ve yürüyüş yolları, Van'a hakikaten yakıştı"(Bisiklet Yolu). "Bisiklet şehri Konya'da bisiklet tramvayı ve bisiklet aparath otobüs dönemi başladı"(Bisiklet Tramvayı, Bisiklet Otobüsü). "Bisiklet dostu şehir olma yolunda büyük bir adım daha... Işıklarda bisiklet molası için teşekkürler İzmir"(Mola İstasyonu). "SAKBİS'ler ile sorunsuz ve sağlıklı ulaşım imkânımız var" (Akıllı Bisiklet Sistemi). "Bisiklet Evi ile İstanbul bisiklet dostu bir şehir olmaya bir adım daha yaklaştı" (Bisiklet Evi). "Kopenhag'ın bisiklet köprülerine bir yenisi daha eklendi" (Bisiklet Köprüsü). "7. Geleneksel Bisiklet Turu", "Spor ve săğlk çerçevesinde, bisikletin sağlıkl ve en ekonomik ulaşım aracı mesajı ile pedal çevirdiler" (Etkinlik). "Bugün Budapeşte'nin en etkin sivil toplum örgütlerinden geleneksel şehir turuna ilk defa katılip on binlerce bisikletliyle beraber şehrin daha da bisiklet dostu bir şehir olması için pedal çevirdik" (Etkinlik). "Bisiklet sporunu çok önemsiyor, şehrimizde de bisiklet kullanımını yaygıılaştırma noktasında çalışmalar gerçekleştiriyoruz" (Bisiklet Sporu). "Bisikletleri şehir trafiğinden etkilenmeden gezdik. Hem de spor yapmış olduk (Bisiklet Sporu)". "Bisiklet Dostu Şehir; Kopenhag; Şehirde $350 \mathrm{~km}$ bisiklet yolu var ve nüfusun yarısı bisiklet kullanıyor" (Bisiklet Kullanımı). "Sosyal 
mesafe için toplu taşıma yerine bisiklet kullanılması önerisi"(Toplu Taşıma Aracına Alternatif). "Mesela Bisiklet Dostu kentler yaratmaktansa, Bisiklet dostu insanlar yaratmak" (Olumsuz) ifadeleri örnek olarak gösterilebilir.

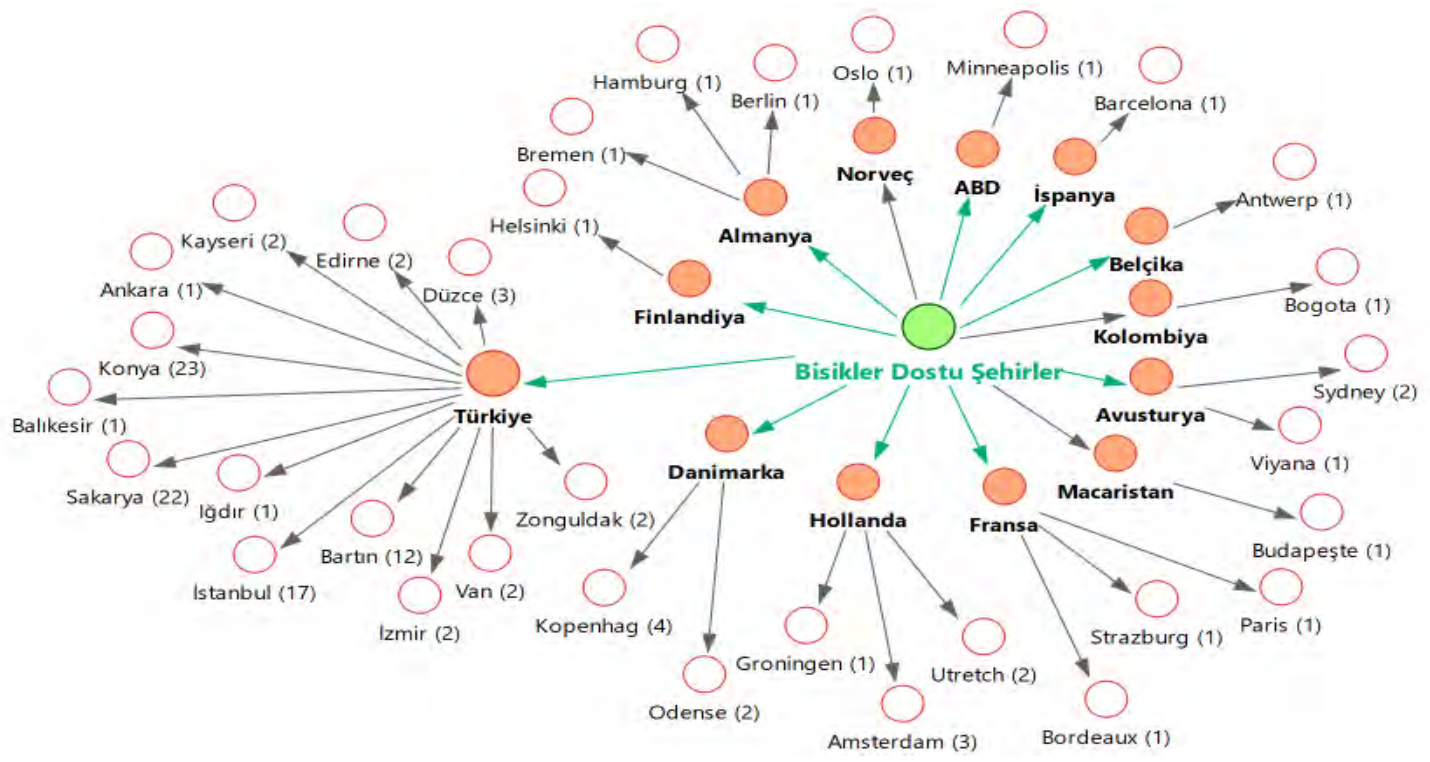

Şekil 2. Paylaşımlarda Geçen Bisiklet Dostu Kentlerin Hiyerarşik Kod Modeli

Şekil 2' de paylaşımlarda bisiklet dostu şehir olarak ilişkilendirilen destinasyonların ülkelere göre dağılımları gösterilmektedir. Türkiye'de en fazla Konya $(n=23)$ ve Sakarya $(n=22)$ illerinin bisiklet dostu şehir olduğu ile ilgili paylaşımlar yapılmıştır. Daha sonra sırasıyla, İstanbul (n=17), Bartın $(\mathrm{n}=12)$, Düzce $(\mathrm{n}=3)$, Edirne $(\mathrm{n}=2)$, Kayseri $(\mathrm{n}=2)$, İzmir $(\mathrm{n}=2)$, Van $(\mathrm{n}=2)$, Zonguldak $(\mathrm{n}=2)$, Ankara $(n=2)$ ve Iğdır $(n=1)$ ile ilgili paylaşımlar mevcuttur. Hollanda'da bisiklet dostu şehir olarak, Amsredam (3), Utretch $(\mathrm{n}=2)$ ve Groningen $(\mathrm{n}=1)^{\prime}$ den bahsedilmektedir. Danimarka'da Kopenhag $(n=4)$ ve Odense $(n=2)$; Fransa'da Strazburg $(n=1)$, Bordeaux $(n=1)$ ve Paris $(n=1)$; Avusturya'da Sydney ( $n=2)$ ve Viyana ( $n=1)$; Almanya'da Berlin $(n=1)$, Hamburg $(n=1)$ ve Bremen $(n=1)^{\prime}$ in bisiklet dostu şehir olduğuna yönelik ifadeler yer almaktadır.

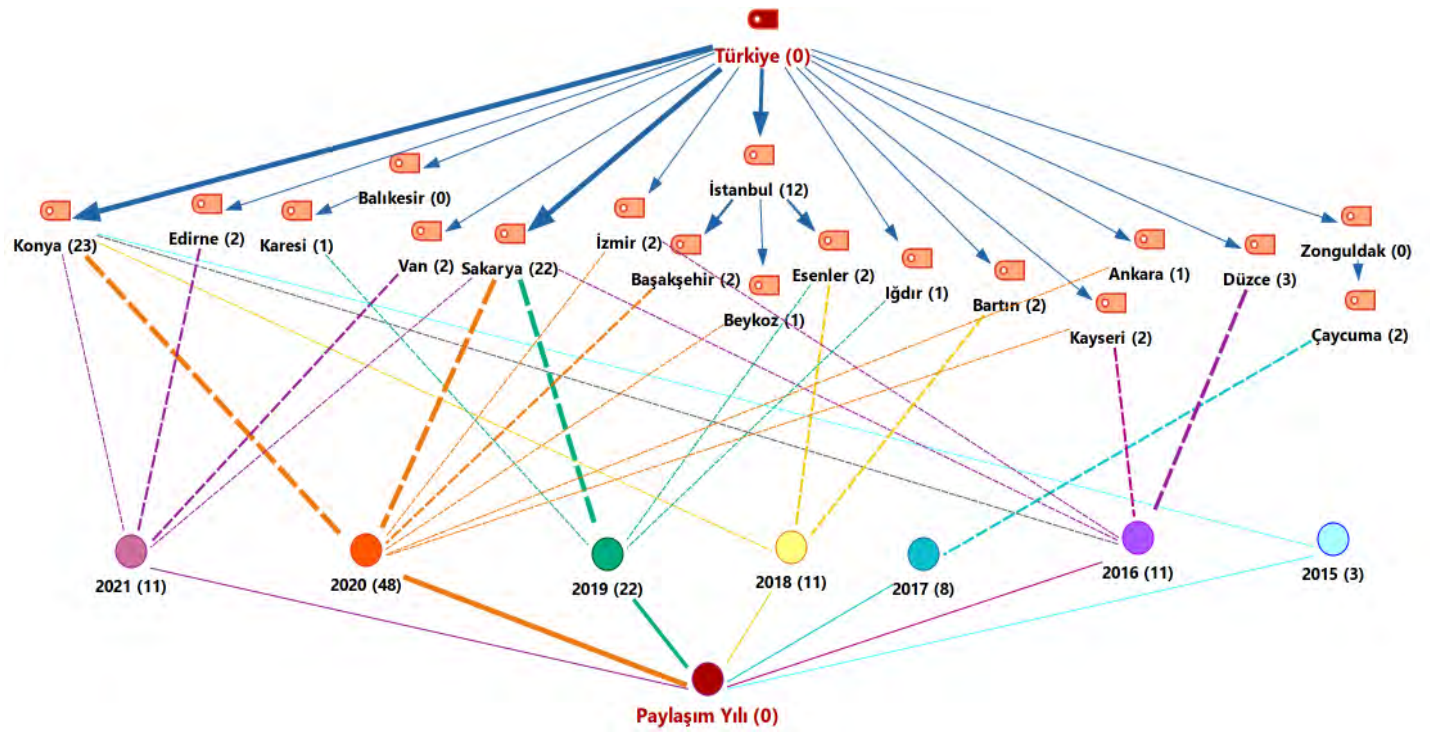

Şekil 3. Türkiye'de Bisiklet Dostu Şehirlere Yönelik Paylaşımların Yıllara Göre Karşılaştırılması 
Şekil 3'te Türkiye' de bisiklet dostu şehirler olarak ilişkilendirilen destinasyonlara yönelik yapılan paylaşımların yıllara dağılımları yer almaktadır. Konya ili ile ilgili en fazla paylaşım 2020 yılında yapılmıştır. Sakarya ili ile ilgili 2021, 2020, 2019 ve 2016 yıllarında paylaşım yapıldığı tespit edilmiştir. 2018 yılında, Konya, Esenler ve Bartın'a yönelik paylaşım yapılmıştır. 2016 yılında, Konya, Sakarya, İzmir, Kayseri ve Düzce'ye yönelik paylaşım yapılırken, 2017 yılında sadece Çaycuma ilçesi ve 2015 yılında sadece Konya iline yönelik paylaşımların yapıldığı görülmektedir.

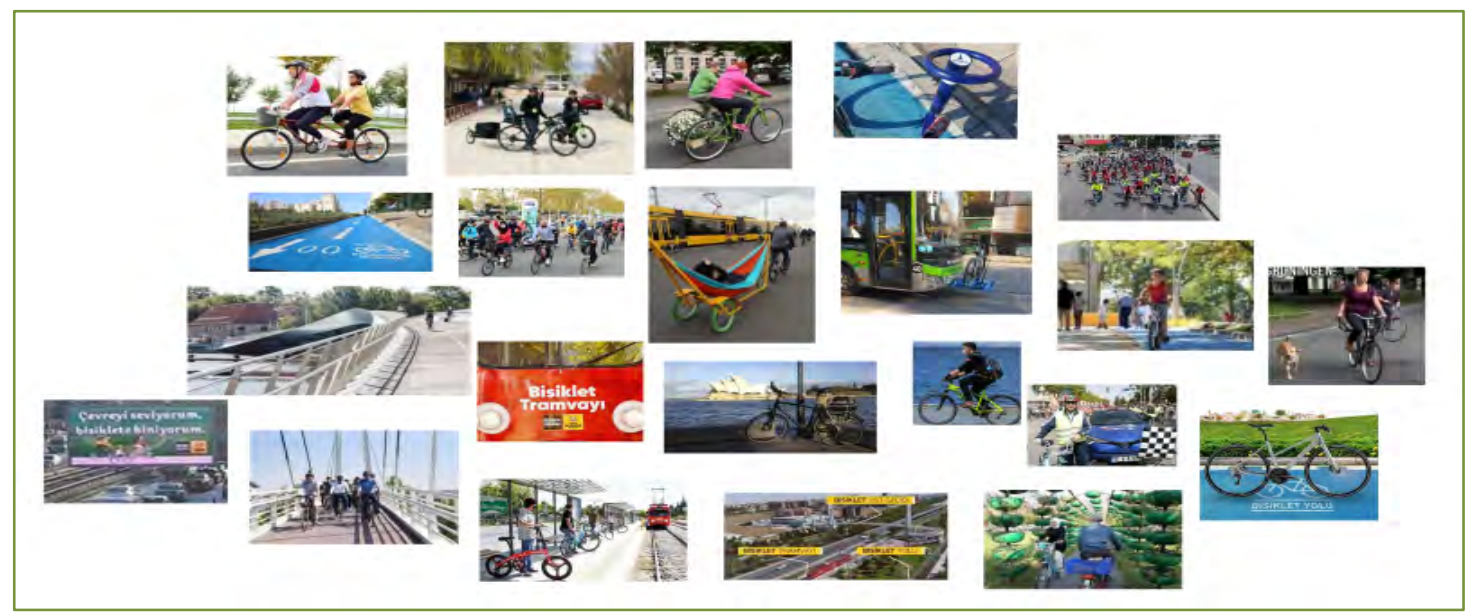

Şekil 4. Paylaşımlarda Kullanılan Fotoğraflardan Örnekler

Şekil 4'te bisiklet dostu şehirlere yönelik yapılan paylaşımlarda kullanılan fotoğraflara yönelik bazı örnekler sunulmuştur. Paylaşılan fotoğraflar incelendiğinde, bisiklet tramvayı, otobüslerde bisiklet taşıma aparatı, trafik ışıklarında mola istasyonu, bisiklet kültürünün oluşmasına yönelik bilgilendirme duyuruları, bisiklet köprüsü, bisiklet yolu, bisiklet çeşitleri ve bisiklet etkinliklerinin yer aldığı görülmektedir. Fotoğrafların paylaşıldığı destinasyonlar arasında Kopenhag, Sydney, Budapeşte, Konya, Sakarya ve İzmir yer almaktadır.

\section{SONUÇ}

Şehirlerde ana ulaşım şekli olarak bisiklet kullanma fikri hızla benimsenmektedir. Güvenli ve uygun bisiklet rotaları oluşturmak, çağdaş şehirlerdeki ana kalkınma görevlerinden biri haline gelmiştir (Zayed, 2016:210). Bu, modern şehirlerin yaşanabilirliğini tehdit eden büyük çevresel, sağlık ve sosyal zorluklardan kaynaklanmaktadır. Sürdürülebilir ulaşım sistemlerinin ana unsurları olarak yürüyüş ve bisiklete binme benimsenmektedir. Bisikletler, fiziksel olarak arabalardan ve toplu taşıma araçlarından daha küçük olduğundan, şehir sokaklarında trafik sıkışıklığın azalmasına katkı sağlayacaktır. Bununla birlikte bisikletin kullanımı için fosil yakıt gerektirmemesi nedeniyle motorlu taşıtlardan daha az maliyetli olduğu düşünülmektedir. Bu nedenle bisikletçiler, bakım ve park maliyetlerinin yanı sıra yakıt maliyetinden de tasarruf edebilirler. Bisiklet kullanımının ekonomik tasarruf sağlamasının yanı sıra turistik bir ürüne dönüştürülmesi sayesinde turizm paydaşlarına ekonomik fayda sağlamaktadır.

Bisiklet turizmi; altyapı, konaklama, ulaşım, güvenlik, hava durumu, topluluk, doğal ve insan yapımı cazibe merkezlerinin farklı boyutlarını içermektedir. Tüm bu boyutlar dikkatli bir şekilde organize edilmelidir. Böylelikle bisiklet turizmi, sürdürülebilir turizm şekli ile kırsal ve gelişmekte olan destinasyonların ekonomik kalkınmasını teşvik etme potansiyeline sahiptir (Soyalp, 2018). Bisiklet turizmi kapsaminda dünya genelinde bisiklet festivalleri düzenlenmektedir. Gittikçe yaygınlaşan bisiklet festivalleri, tek bir başlıkta düzenlendiği gibi tur 
ve yarışları da içeren bir etkinlik şeklinde organize edilmektedir. Birçok ülke/bölge/şehrin kendine özgü bisiklet festivalleri, çeşitli bisiklet aktivitelerini barındırarak farklı bisiklet kullanıcılarına ev sahipliği yapmaktadır. Bisiklet festivalleri, turizm pazarında farklılık yaratarak rekabet edebilirliği desteklemektedir (Uğuz ve Özbek, 2018). Bu doğrultuda çalışmada, önemli bir niş pazar olan bisiklet turizmi kapsamında bisiklet dostu şehir uygulamaları değerlendirilmiştir.

Araştırma bulgularından yola çıkarak, Türkiye'de en fazla Konya $(n=23)$ ve Sakarya $(n=22)$ illerinin bisiklet dostu şehir olduğu ile ilgili paylaşımlar yapılmıştır. Hollanda'da Amsredam (3), Utretch $(n=2)$ ve Groningen $(n=1)$; Danimarka'da Kopenhag $(n=4)$ ve Odense $(n=2)$; Fransa'da Strazburg $(n=1)$, Bordeaux $(n=1)$ ve Paris $(n=1)$; Avusturya'da Sydney $(n=2)$ ve Viyana $(n=1)$; Almanya'da Berlin $(n=1)$, Hamburg $(n=1)$ ve Bremen $(n=1)^{\prime}$ in bisiklet dostu şehir olduğuna yönelik ifadelerin yer aldığı tespit edilmiştir. Uğuz ve Özbek (2018) çalışmasında belirttiği gibi bisiklet turizminde etkinlikler önemli bir yere sahiptir. Bisiklet dostu şehir uygulamaları kapsamında bisiklet etkinliklerin teşvik edildiği görülmektedir. Buna paylaşım ifadelerinden örnek olarak, "Bisiklet sporunu çok önemsiyor, şehrimizde de bisiklet kullanımını yaygınlaştırma noktasında çalışmalar gerçekleştiriyoruz" (Etkinlik). "Hafta sonu sabah sporunu bisiklet ile yapanlar burada mı? Beykoz Bisiklet Turu" (Etkinlik). "Avrupa Hareketlilik Haftası" (Etkinlik). Tarihi Yarımada'da "Bisiklet Turu etkinliği" (Etkinlik) gösterilebilir. Barney (2018) ve Oja vd. (2011)'nın belirttiği gibi bisikletin ekonomik bir ulaşım aracı olduğu "En ekonomik ulaşım aracı" (Ekonomik Ulaşım Aracı) paylaşım ifadesi ile desteklenmektedir. Aynı zamanda, rekreatif faaliyet olarak bisiklet kullanımı sağlıklı yaşam için önemli bir araç olduğunda dair ifadeleri de Kamel vd., (2020) yapmış olduğu çalışma sonuçları ile desteklenmektedir.

Çalışmada, Buehler ve Pucher (2012) çalışması ile doğru orantılı olarak Hollanda Utrecht'da, nüfusun yarıdan fazlası ulaşımını bisikletle sağlandığı tespit edilmiştir. Bu doğrultuda bisiklet turizminden daha fazla pay almak için bisiklet dostu şehir imajının oluşturulmasına katkı sağlayan bisiklet dostu şehir uygulamalarında yerel halkın önemli bir role sahip olduğu görülmektedir. Bisiklet dostu şehir uygulamaları olarak bisiklet altyapısının destinasyon yönetim örgütlerinin desteğiyle geliştirilmesi, bisiklet turizminde destinasyonların çekiciliğinin artırılmasına katkı sağlayacaktır. Bu girişim faaliyetlerine örnek olarak bazı paylaşım ifadeleri şu şekildedir. Sakarya'da uygulanan SAKBİS akıllı sistemleri Lyua vd., (2020) çalışmasında bahsedilen bisiklet kullanım türleri arasında yer almaktadır. Twitter'da "Bisiklet kullanımını yayginlaştırmak, insan ve çevre odakl ulaşım alternatifleri oluşturmak ve bisiklet dostu şehir olma çalışmalarına devam edeceğiz" (Şehirlerin Uygulamaları) paylaşımı, Arellanaa vd., (2020) çalışmasında bahsettiği birçok hükümetin bisiklet sürmeyi teşvik ettiğine yönelik ifadesi ile desteklemektedir. Ayrıca Zayed (2016) çalışması ile aynı doğrultuda olarak toplu taşıma araçlarına alternatif olduğu paylaşımı yapılmıştır. "Geleceğin bisikletçilerini eğitmeye devam ediyoruz. Şahin Ortaokulu öğrencilerini Ayçiçeği Bisiklet Vadisi'nde ağırlayarak güvenli sürüş eğitimi ve sağllklı yaşam için spor yapmanın önemini paylaştık" (Şehirlerin Uygulamaları, Bisiklet Sürme Eğitimi). "Konya'da bisiklet tamir istasyonlarının sayısını 35'e yükseltildi" (Şehirlerin Uygulamaları, Bisiklet Tamir İstasyonu).

Sonuç olarak, destinasyon yönetim örgütlerinin bisiklet yolları ile ilgili çalışmalarının yoğun bir şekilde devam ettiği görülmektedir. Destinasyon yönetim örgütlerinin bisiklet yollarına yönelik çalışmalarının yanında, bisiklet trafik ışıkları, bisiklet parkı, bisiklet tamir istasyonu, trafik 1şıklarında mola istasyonları, toplu taşıma araçlarında (otobüs, tramvay vd.) bisiklet taşıma imkânı, bisiklet kültürünün oluşmasına yönelik bilinçlendirme faaliyetleri ve etkinlikler gibi uygulamalarının daha sınırlı kaldığı tespit edilmiştir. Bu nedenle belediyelerin bisiklet dostu şehir uygulama girişimlerinde bahsi geçen tüm uygulamaları hayata geçirmesi önerilmektedir. Bu sayede bisiklet turizminde önemli olan altyapı, etkinlik, bilinçlendirme ve tanıtım faaliyetleri 
gibi uygulamalar, mevcut bisiklet turistleri için daha güvenli ve zengin tatil deneyimi yaşama imkânı sunarken, potansiyel bisiklet turisti için önemli bir çekicilik unsurunu oluşturacaktır. Destinasyon yönetim örgütlerinin bisiklet dostu şehir olma çabalarında, bisiklet dostu otel ve restoran sayısının artmasına yönelik girişimleri teşvik etmesi önerilmektedir. Ayrıca seyahat acentalarının bisiklet turlarını artırmasının bisiklet turizminin gelişmesine katkı sağlayacağ öngörülmektedir. İlerideki çalışmalarda Copenhagenize Index'inde bulunan şehirlerin bisiklet dostu uygulamaları incelenebilir.

\section{KAYNAKÇA}

Arellanaa, J., Saltarina, M., Larranagab, A. I. M., Gonzaleza, I. V. and Henaoa, C. A. (2020). Developing an Urban Bikeability Index for Different Types of Cyclists as A Tool to Prioritise Bicycle Infrastructure Investments, Transportation Research Part A, 139, 310-334.

ARUP, (2019). Inclusive Cycling in Cities and Towns, file:///C:/Users/lenovo/Downloads/Inclusive_cycling_in_cities_and_towns.pdf, [Erişim Tarihi: 10.11.2020].

ARUP (2005). Cycle Tourism in the Hunter Region, Hunter Cycling Network.

Aşan, K. ve Akoğlan Kozak, M. (2015). Postmodern Turist Deneyimi ve Bisiklet Turizmi, International Journal of Eurasia Social Sciences, 6(21): 265-288.

Baltacı, A. (2019). Nitel Araştırma Süreci: Nitel Bir Araştırma Nasıl Yapılır?, Ahi Evran Üniversitesi Sosyal Bilimler Enstitüsü Dergisi, 5(2): 368-388.

Bauman, A. and Rissel, C., (2009). Cycling and health: an opportunity for positive change? Med. J. Aust. 190(7): 347-348.

Barney, R. (2018). Bicycle Urbanism Reimagining Bicycle Friendly Cities, New York: Routledge.

Bassett, D., Pucher, J., Buehler, R., Thompson, D. and Crouter, S., (2008). Walking cycling, and obesity rates in Europe, North America, and Australia. J. Phys. Act. Health 5(6): 795-814.

Beierle, H. (2011). Bicycle Tourism as A Rural Economic Development Vehicle, Department of Planning, Public Policy and Management, University of Oregon. https://scholarsbank.uoregon.edu/xmlui/handle/1794/11679.

Buehler, R. and Pucher, J. (2012). Cycling to Work in 90 Large American Cities: New Evidence on the Role of Bike Paths and Lanes, Transportation, 39(2): 409-432.

Buning, R. J. and Gibson, H. J. (2016). The Role of Travel Conditions in Cycling Tourism: Implications for Destination and Event Management, Journal of Sport \& Tourism, 1-19.

Cengiz, T. ve Kahvecioğlu, (2016). Sürdürülebilir Kent Ulaşımında Bisiklet Kullanımının Çanakkale Kent Merkezi Örneğinde İncelenmesi, Tekirdă̆ Ziraat Fakültesi Dergisi, 13(2): 55-66.

Chang, H. W. and Chang, H. L. (2013). A Strategic Study of Bicycle Tourism in Taiwan, Journal of the Eastern Asia Society for Transportation Studies, 5, 1675-1684.

Chevalier, A. and Xu, L. (2020). On the Applicability of a Western Bikeability Index in the Chinese Context, International Review for Spatial Planning and Sustainable Development, 8(1): 59-93.

City of Copenhagen. (2015). City of Copenhagen Municipal Plan 2015: The coherent city. [PDF file]. https://kp15.kk.dk/sites/kp15.kk.dk/files/municipal_plan_2015.pdf, [Erişim Tarihi: 20.10.2020]. 
Copenhagenize Index, (2020). https://copenhagenizeindex.eu/about/faq, [Erişim Tarihi: 20.10.2020].

Creswell, J. W. (2002). Educational Research: Planning, Conducting, and Evaluating Quantitative, Prentice Hall Upper Saddle River, NJ.

Çelik, H., Başer Baykal, N. ve Kılıç Memur, H. N. (2020). Nitel Veri Analizi ve Temel İlkeleri, Eğitimde Nitel Araştırmalar Dergisi, 8(1): 379-406.

Çelik Uğuz, S. ve Özbek, V. (2018). Destinasyon Sadakatini Etkileyen Faktörler: Bisiklet Turizmi ve Burhaniye Bisiklet Festivali Örneği, IREM, 6(2): 84-102.

Duran, E. Sevinç, F. and Harman, S. (2018). Cycle Tourism as An Alternative Way of Tourism Development in Çanakkale, Turkey, Journal of Awareness, 3(4): 25-34.

Faulks, P., Dodd, J. and Ritchie, B. (2008). Bicycle Tourism as an Opportunity for Recreation and Restoration? Investigating the Motivations of Bike Ride Participants, In J. Fountain, and K. Moore (Eds.), Re-creating Tourism: New Zealand Tourism Hospitality Research Conference (1-27). Lincoln University.

Gazzola, P., Pavione, E., Grechi, D. and Ossola, P. (2018). Cycle Tourism as a Driver for the Sustainable Development of Little-Known or Remote Territories: The Experience of the Apennine Regions of Northern Italy, Sustainability, 10(6): 1863.

Gibling, S. (2006). Trail Events: Mountain Bike World Championships, 2006 Australasian Cycle Tourism Conference, Adelaide, Rotorua.

Goeft, U. and Alder, J. (2001). Sustainable Mountain Biking: A Case Study from the Southwest of Western Australia, Journal of Sustainable Tourism, 9, 193-211.

Gökçe, O. (2006). İ̧̧erik Analizi: Kuramsal ve Pratik Bilgiler. Ankara: Siyasal Kitabevi.

Griswold, J., Medury, A. and Schneider, R. (2011). Pilot Models for Estimating Bicycle Intersection Volumes, Transportation Research Record, 2247, 1-7.

Handy, S. (2020). Making US Cities Pedestrian and Bicycle Friendly, Transportation, Land Use, and Environmental Planning, 169-187.

İçöz, O., Bozkurt, Y. S. and Günay, T. (2018). Cycling as An Opportunity for Improving Health Tourism in İzmir, Uluslararası Turizm, İşletme, Ekonomi Dergisi, 2(2): 27-35.

Kamel, M., B., Sayed, T. and Bigazzi, A. (2020). A Composite Zonal Index for Biking Attractiveness and Safety, Accident Analysis and Prevention, 137, 1-13.

Kaplan, S., Manca, F., Nielsen, T. A. S. and Prato, C. G. (2014). Intentions to Use Bike-Sharing for Holiday Cycling: An Application of the Theory of Planned Behavior, Trafikdage på Aalborg Universitet.

Karadağ, R. (2014). Okuma İlgisi, Tutumları ve Alışkanlığı Konusunda Yapılmış Çalışmaların Lisansüstü Tezlere Dayalı Analizi: YÖK ve ProQuest Veri Tabanları Örneklemi, Pamukkale Üniversitesi Eğitim Fakültesi Dergisi, 35(I): 1-17.

Kuckartz, A. M. and Kuckartz, U. (2012). Qualitative Text Analysis with MAXQDA, file://C:/Users/lenovo/Downloads/Qualitative_Text_Analysis_with_MAXQDA.pdf, [Erişim Tarihi: 08.11.2020].

Kristinsdottir, S. (2012). A Bicycle Friendly City, a Possibility or a Dream?, Unpublished thesis, Lund University, Sweden. 
Lamont, M. J. (2009). Independent Bicycle Tourism: A Whole Tourism Systems Perspective, Tourism Analysis, 14(5): 605-620.

Lee, C. F., Chen, P. T. and Huang, H. I. (2014). Attributes of destination attractiveness in Taiwanese bicycle tourism: The perspective of active experienced bicycle tourists, International Journal of Hospitality \& Tourism Administration, 15(3): 275-297.

Lee, M. R. (2015). Bicycle Tourism Plan for Economic Development: A Template for Rural Agricultural Towns and A Case Study for the City of Winters, California, California Polytechnic Eyalet Üniversitesi Fakültesi, Yayınlanmamış Yüksek Lisans Tezi, Kaliforniya.

Lyua, Y., Cao, M., Zhang, Y., Yange, T. and Shif, C. (2020). Investigating Users' Perspectives on the Development of Bike-Sharing in Shanghai, Research in Transportation Business \& Management, $100543,1-12$.

Mamur, (2012). Görsel Sanatlar Eğitiminde Nitel Araştırmalar için Bir Doküman: Portfolyo, Eğitim ve Bilim, 37(165): 1-14.

Merriam, S. (1998). Qualitative research and case study applications in education, Revised and expanded from case study research in education, USA: JB Printing.

Neves, J. M. O. and Esperança, J. P. (2011). Bike Usage and Cycle Tourism: The Pattern of Portuguese Associated Bike Riders, Book of Proceedings I- International Conference on Tourism \& Management Studies-Algarve.

Oja, P., Titze, S., Bauman, A., De Geus, B., Krenn, P., Reger-Nash, B. and Kohlberger, T. (2011). Health benefits of cycling: a systematic review, Scand. J. Med. Sci. Sports, 21, 496-509.

Patton, M. Q. (2014). Nitel Araştırma ve Değerlendirme Yöntemleri (M. Bütün ve S. B. Demir, Çev. Ed.), Ankara: Pegem Akademi.

Pratte, J. (2006). Bicycle Tourism: On the Trail to Economic Development, Prairie Perspectives: Geographical Essays, 9(1): 62-84.

Ritchie, B. W. (1998). Bicycle Tourism in the South Island of New Zealand: Planning and Management Issues, Tourism Management, 19: 567-582.

Roberts, P. and Priest, H. (2006). Reliability and Validity in Research, Nursing Standard, 20, 41-45.

Sağlık A., Sağlık E. ve Kelkit A. (2014). Bisiklet Turizmi Açısından Gelibolu Yarımadası Tarihi Milli Parkı'nın İncelenmesi, International Journal of Social and Economic Sciences, 4(1): 84-90.

Simonsen, P. S., Jørgensen, B. and Robbins, D. (1998), Cycling Tourism, Unit of Tourism Research at Recearch Centre of Bornholm, https://crt.dk/wpcontent/uploads/12_rapport_Cycling_tourism.pdf, [Erişim Tarihi: 08.11.2020].

Soyalp, L. (2018). Bicycle Tourism in Ostrobothnia / Finland - Potentials and Challenges, https://www.researchgate.net/publication/343135496_BICYCLE_TOURISM_IN_OSTROBOTHN IA_FINLAND_-Potentials_and_Challenges, [Erişim Tarihi: 12.11.2020].

Soyalp, L. (2017), Bisiklet Turizmi Katılımcilarının Tatil Deneyimi: Yerli Turistler Üzerine Bir Araştırma, Dokuz Eylül Üniversitesi Sosyal Bilimler Enstitüsü, Yayınlanmamış Yüksek Lisans Tezi, İzmir.

Strauss, A. and Corbin, J. M. (1990). Basics of Qualitative Research: Grounded Theory Procedures and Techniques, Sage Publications, Inc.

Strauss, J. and Miranda-Moreno, L.F. (2013). Spatial Modeling of Bicycle Activity at Signalised Intersections, Journal of Transport and Land Use, 6(2): 47-58. 
Streicher, H. and Saayman, M. (2010). Travel Motives of Participants in the Cape Argus Pick N Pay Cycle Tour, South African Journal for Research in Sport, Physical Education and Recreation, 32(1): 121-131.

Sustrans (1999). Sustrans Information Sheets, http://www.sustrans.org.uk/webfiles/Info\%20sheets/ff28.pdf, [Erişim Tarihi: 8.10.2020].

Titze, S., Krenn, P. and Oja, P. (2012). Developing a Bikeability Index to Score the BikingFriendliness of Urban Environments, Journal of Science and Medicine in Sport, 15, 1-33.

Ünüvar, O., Kaya, M. and Sezgin, M. (2017). Bicycle Tourism in Konya Tourism Perspective and A Study on Its Effect on Marketing Konya Tourism as A Destination by Using PEST Analysis, 20(2): 175-182.

Wesley E. M. and Norman W. G. (2011). Evidence on Why Bike-Friendly Cities are Safer for All Road Users, Environmental Practice, 13, 16-27.

Weston, R., Davies, N., Lumsdom, L., McGrath, P., Peeters, P., Ejgelaar, E. and Piket, P. (2012). The European Cycle Route Network Eurovelo: Challenges and Opportunities for Sustainable Tourism, Report IP/B/TRAN/FWC/2010-006/Lot5/C1/SC1, Directorate General for Internal Policies, Policy Department B: Structural and Cohesion Policies, European Parliament, Brussels, Belgium.

Yıldız, D. (2016). Uluslararası Dil Dergilerinde Yayımlanan Makalelerin Amaç/Konu ve Yöntem Açısından İncelenmesi, GEFAD / GUJGEF, 36(2): 399-425.

Zayed M., A. (2016). Towards an Index of City Readiness for Cycling, International Journal of Transportation Science and Technology, 5, 210-225. 